\title{
Pengaruh Karakteristik Struktural dan Manajerial Terhadap Efisiensi Usahatani Padi di Kabupaten Sleman
}

\author{
D 0 : $: 10.18196 /$ agr.2120
}

\begin{abstract}
Efforts to increase productivity of food crops, especially rice by using technology and innovation has been facing problems such as structure of the control and management of agricultural resources. This study aimed to identify the factors of farmer's structural and managerial characteristics that affect paddy farming efficiency in Sleman. Survey conducted on wetland rice farmers in rural and sub urban areas that represent the condition of the structural and manjerial characteristics that owned by farmers in Sleman. Analysis of stochastic frontier production function with the inclusion of the inefficiency effects model was conducted to identify determinants of production and the factors that affect the efficiency of farming. The result showed that the
\end{abstract}

structural characteristics that influence the rice farming efficiency are the water irrigation source distance and the farm location, while the managerial characteristics factors are age, income outside the farm, participation in a group, experience and access to credit.

Key words: structural and managerial characteristics, efficiency, rice farming.

\section{INTISARI}

Usaha peningkatan produktivitas tanaman pangan khususnya padi dengan pemanfaatan teknologi dan inovasi menghadapi permasalahan berupa struktur penguasaan dan pengelolaan sumberdaya pertanian. Penelitian ini bertujuan untuk mengidentifikasi faktor karakteristik struktural dan manajerial petani yang mempengaruhi efisiensi usahatani padi di Kabupaten Sleman. Survei dilakukan terhadap petani padi lahan sawah di kawasan pedesaan dan peri urban yang merepresentasikan kondisi karakterstik struktural dan manjerial yang dimiliki petani di Kabupaten Sleman. Analisis fungsi produksi stochastic frontier dengan memasukkan model efek inefisiensi dilakukan untuk mengidentifikasi faktor penentu produksi serta faktor-faktor yang mempengaruhi efisiensi usahatani. Hasil analisis menunjukkan bahwa karakteristik struktural yang berpengaruh terhadap efisiensi usahatani padi adalah jarak sumber air irigasi dan lokasi usahatani; sedangkan karakteristik manajerial yang berpengaruh terhadap efisiensi usahatani adalah umur, pendapatan luar usahatani, partisipasi dalam kelompok, pengalaman dan akses terhadap kredit.

Kata kunci: karakteristik struktural dan manajerial, efisisensi, usahatani padi.

\section{PENDAHULUAN}

Pertanian berkelanjutan menjadi isu penting di negara berkembang maupun negara sedang berkembang. Di negara sedang berkembang isu ini lebih mendesak untuk dibahas, keterbatasan sumberdaya alam dan teknologi yang tersedia memerlukan upaya yang lebih kuat dalam 
meningkatkan produksi pertanian untuk memenuhi kebutuhan penduduk yang semakin meningkat.

Banyak studi dilakukan untuk meningkatkan produksi pertanian melalui peningkatan efisiensi usahatani berdasarkan sumberdaya dan teknologi yang ada. Sejumlah aplikasi empiris telah dilakukan untuk mengukur efisiensi dan keberlanjutan pertanian di banyak negara. Investasi masyarakat untuk meningkatkan keberlanjutan usahatani membutuhkan penilaian yang tepat terhadap efisiensi usaha yang telah dijalankan oleh petani dan identifikasi sumberdaya yang tidak efisien dalam rangka mengembangkan kebijakan dan mengembangkan inovasi untuk meminimalkan inefisiensi (Sherlund et al., 2002).

Keberlanjutan produksi padi dapat dirancang dengan mengukur efisiensi pada tingkat usahatani, mengidentifikasi faktor-faktor yang berkaitan dengan efisiensi produksi, dan merumuskan kebijakan untuk masa yang akan datang. Sebagai sebuah alternatif peningkatan output produksi, upaya dapat dilakukan melalui peningkatan efisiensi teknik. Efisiensi teknik artinya berproduksi dengan menggunakan sumberdaya lebih efisien (Sharma dan Leung, 2000). Lebih dari itu, peningkatan pendapatan melalui peningkatan efisiensi akan memberikan gambaran bahwa petani dapat meningkatkan pendapatan dengan keterbatasan sumberdaya yang ada. Oleh karena itu, efisiensi penggunaan sumberdaya akan menjadi tolok ukur penting dalam mengembangkan keberlanjutan usahatani padi untuk mendukung program ketahanan dan kemandirian pangan.

Efisiensi teknik merupakan sebuah ukuran relatif dari kemampuan manajerial petani pada tingkat teknologi yang ada. Hal ini berarti efisiensi teknik terjadi karena adanya perbaikan keterampilan teknis dan kemampuan manajerial dari petani. Menurut Van Passel (2006) kapabilitas manajerial berhubungan dengan umur, pendidikan baik formal maupun non formal, pengalaman, akses terhadap penyuluhan, kredit, dan pasar.

Dalam studinya yang dilakukan pada tahun 2007, Bravo-Ureta et al. menggunakan data yang dipublikasikan antara tahun 1979 sampai tahun 2005 diperoleh 167 studi efisiensi. Komoditas yang paling banyak dianalisis adalah padi, diikuti oleh peternakan sapi perah, dan usahatani keseluruhan. Dalam studi tersebut penelitian hortikultura relatif terbatas hanya sekitar 2 persen dari keseluruhan penelitian.
Banyak studi sudah mengkaitkan pengaruh faktor sosial, ekonomi dan ekologi terhadap efisiensi teknik. Umur petani, pendidikan, akses terhadap penyuluhan, akses terhada kredit, agro-ekologi, luas lahan yang diusahakan, jumlah persil yang dimiliki, jumlah tanggungan keluarga, gender, sewa, akses pasar, akses terhadap teknologi (pupuk, pestisida, traktor, benih, intervensi pemerintah) mempunyai pengaruh positif terhadap efisiensi teknik (Ahmad et al., 2002; Basnayake and Gunaratne, 2002; Tchale dan Sauer, 2007 dan 2009).

Bozoglu and Ceyhan (2007) menilai efisiensi teknik dari produksi sayuran di Turki dengan menggunakan pendekatan SFA. Determinan yang menentukan efisiensi teknik meliputi umur petani, pengalaman, pendidikan, ukuran keluarga, dummy pendapatan di luar usahatani, dummy kredit, dummy partisipasi wanita, dan skor informasi. Hasilnya memperlihatkan bahwa rata-rata efisiensi teknik adalah 0,82 . Sumber penyebab inefisiensi yang positif dan berpengaruh secara nyata adalah umur petani. Namun pengalaman, pendidikan, penggunaan kredit, partisipasi wanita, dan skor informasi mempunyai tanda negatif dan berpengaruh nyata terhadap inefisiensi teknik.

Selanjutnya Abedullah et al. (2007) menggunakan fungsi produksi stochastic frontier untuk menentukan strategi peningkatan produksi padi di Punjab. Hasil analisis menunjukkan bahwa pestisida tidak berpengaruh secara signifikan terhadap produktivitas padi, sementara pupuk memiliki dampak negatif terhadap produktivitas karena komposisi unsur hara $\mathrm{N}, \mathrm{K}$ dan $\mathrm{K}$ yang tidak tepat. Hal ini mengindikasikan minimnya diseminasi layanan penyuluhan. Oleh karena itu lembaga penyuluhan seharusnya melakukan penguatan untuk peningkatan produktivitas padi serta melindungi sumberdaya alam utama, air tanah untuk generasi yang akan datang. Namun demikian, studi ini belum menganalisis faktor sumberdaya alam terutama air irigasi.

Meuya et al. (2008) melakukan penelitian yang bertujuan untuk mengestimasi tingkat efisiensi teknik dari 233 petani jagung di Tanzania, menggunakan fungsi produksi stochastic frontier, juga untuk melihat faktor penentu yang mempengaruhi inefisiensi sehingga dapat ditemukan cara untuk meningkatkan produksi dan produktivitas petani gandum berskala kecil di Tanzania. Efisiensi teknik bervariasi antara 1,1 persen sampai 91 persen dengan rata-rata $T E=60,6$ persen. Faktor yang mempunyai pengaruh negatif terhadap efisiensi teknik antara lain: pendidikan rendah, ketidaktersediaan akses 
kredit, keterbatasan kapital, fragmentasi lahan, ketidaktersediaan input, dan tingginya harga input. Petani yang mempunyai pendapatan di luar usahatani ditemukan lebih efisien, sedangkan petani yang menggunakan pestisida kimia kurang efisien dalam mengusahakan usahataninya.

Bakhsh dan Hassan (2008) melihat hubungan antara efisiensi teknik dengan kemampuan manajerial. Dalam penelitiannya dianalisis hubungan efisiensi teknik dengan kemampuan manajerial dari petani wortel. Tingkat pendidikan dan keterbukaan pada jasa penyuluhan merupakan faktor penentu dari kemampuan manajerial petani wortel. Pendidikan dan penyuluhan mempunyai pengaruh yang signifikan terhadap efisiensi teknik. Dengan demikian peningkatan pendidikan dan perluasan penyuluhan dapat meningkatkan efisiensi teknik dan mengurangi pengunaan sumberdaya yang berlebihan.

Obare et al. (2010) melakukan penelitian untuk melihat tingkat efisiensi alokatif sumberdaya dari petani kentang dan melihat faktor yang mempengaruhi efisiensi alokatif. Hasilnya menunjukkan pengalaman, akses terhadap kredit, akses terhadap penyuluhan, keanggotaan dalam kelompok berpengaruh positif dan signifikan terhadap efisiensi alokatif. Hasan dan Islam (2010) menggunakan data cross section dari tiga daerah di Bangladesh dengan pendekatan fungsi produksi Cobb Douglas menyimpulkan bahwa pendidikan dan training mempunyai pengaruh yang signifikan terhadap inefisiensi teknik.

Sebagian besar penelitian tentang efisiensi masih didominasi faktor teknis dan sosial ekonomi sebagai variabel yang berpengaruh terhadap efisiensi. Masih sedikit penelitian yang mengulas tentang faktor lingkungan, seperti irigasi dan musim tanam yang berhubungan dengan cuaca, serta faktor sosial ekonomi status penguasaan lahan. Semua variabel tersebut belum banyak dibahas dalam menganalisis efisiensi usahatani. Faktor-faktor tersebut banyak dijumpai pada usahatani di negara berkembang dan daerah tropis yang dapat menjalankan usahatani sepanjang tahun dengan kondisi cuaca atau musim yang berubah-ubah.

Upaya peningkatan produktivitas padi di Pulau Jawa, sebagai pemasok 60 persen produksi pangan nasional di Indonesia, yang dilakukan melalui inovasi teknologi mengalami hambatan turunnya luasan lahan sawah dan turunnya daya dukung lahan dan lingkungan akibat pemakaian bahan kimia secara intensif yang menyebabkan pencemaran tanah, air, lingkungan tempat tinggal, maupun kesehatan manusia itu sendiri.

Berkembangnya sektor industri, jasa dan property pada era pertumbuhan ekonomi telah memberikan tekanan pada sektor pertanian, terutama lahan sawah. Oleh karena itu program intensifikasi menjadi penting untuk peningkatan produksi. Intensifikasi ditujukan untuk meningkatkan produktivitas yang dapat dicapai melalui peningkatan efisiensi atau terobosan teknologi. Dalam kondisi teknologi yang tetap, peningkatan efisiensi adalah upaya tepat untuk peningkatan produktivitas.

Kabupaten Sleman merupakan salah satu sentra produksi padi di Yogyakarta, dengan areal lahan sawah berada di bagian utara Daerah Istimewa Yogyakarta yang relatif dekat dengan sumber irigasi. Namun demikian, Kabupaten Sleman memiliki pusat pertumbuhan ekonomi non pertanian yang relatif tinggi dibanding wilayah lain di Daerah Istimewa Yogyakarta, khususnya di wilayah yang berbatasan langsung dengan Kota Yogyakarta. Kondisi tersebut memberikan tekanan pada sektor pertanian, sehingga wilayah ini rentan terhadap perubahan struktur dan status kepemilikan lahan karena terjadi alih fungsi lahan. Hal demikian, akan berpengaruh pada efisiensi dan keberlanjutan usahatani padi di Kabupaten Sleman

Berdasarkan permasalahan di atas, perlu dilakukan telaah untuk mengidentifikasi faktor sosial ekonomi (karakterisitik manajerial) petani dan faktor struktural, khususnya aspek lingkungan, yang mempengaruhi efisiensi usahatani padi di Kabupaten Sleman.

\section{METODE PENELITIAN}

Penelitian ini dilakukan di kabupaten yang memiliki lahan sawah terluas di Daerah Istimewa Yogyakarta yaitu Kabupaten Sleman (BPS D.I. Yogyakarta, 2013). Penentuan lokasi pengambilan sampel didasarkan pada aliran sungai irigasi yang melintasi Kabupaten Sleman yang memiliki nilai pencemaran hasil analisis dari Badan Lingkungan Hidup DI Yogyakarta. Dari lima sungai aliran irigasi yang melintasi Kabupaten Sleman, diambil 10 titik lokasi pengambilan sampel, terdiri dari enam lokasi di kawasan pedesaan dan empat lokasi di kawasan peri urban. Dari masing-masing lokasi sampel diambil lima sampel petani secara simple random sampling, sehingga jumlah sampel dalam penelitian ini sebanyak 50 petani. Data usahatani diambil pada musim hujan dan musim kemarau 2013/2014. 
Untuk menganalisis kinerja usahatani padi di Kabupaten Sleman digunakan analisis kinerja ekonomi dari usahatani padi, determinan dari kinerja ini diukur dengan efisiensi teknik. Untuk menganalisis efisiensi teknik digunakan model Stochastic Frontier Analysis (SFA). Model ini digunakan untuk mengestimasi fungsi produksi frontier dengan spesifikasi model sebagai berikut:

$\operatorname{Ln} Y_{i}=\hat{a} o+\hat{a}_{1} \ln X_{1}+\hat{a}_{2} \ln X_{2}+\hat{a}_{3} \ln X_{3}+\hat{a}_{4} \ln X_{4}+\hat{a}_{5} \ln$ $\mathrm{X}_{5}+\hat{\mathrm{a}}_{6} \ln \mathrm{X}_{6}+\hat{\mathrm{a}}_{7} \ln \mathrm{X}_{7}+\hat{\mathrm{a}}_{8} \ln \mathrm{X}_{8}+\mathrm{d}_{1} \mathrm{D}_{1}+v_{i}-u_{i} \ldots$

Dengan :

$\mathrm{Y}_{\mathrm{i}}=$ produksi total padi (usahatani ke i) $(\mathrm{kg})$

$\mathrm{X}_{1}=$ luas lahan yang digunakan untuk usahatani padi ke i (ha)

$\mathrm{X}_{2}=$ jumlah benih $(\mathrm{kg})$ untuk usahatani padi ke $\mathrm{i}$

$\mathrm{X}_{3}=$ jumlah pestisida (liter) untuk usahatani padi ke $\mathrm{i}$

$\mathrm{X}_{4}=$ jumlah pupuk $\mathrm{N}(\mathrm{kg})$ yang digunakan usahatani padi ke-i

$\mathrm{X}_{5}=$ jumlah $\mathrm{P}(\mathrm{kg})$ yang digunakan usahatani padi ke-i

$\mathrm{X}_{6}=$ jumlah pupuk kandang/organik $(\mathrm{kg})$ untuk usahatani padi ke i

$\mathrm{X}_{7}=$ jumlah tenaga kerja (HKP) untuk usahatani padi ke i

$\mathrm{X}_{8}=$ polusi irigasi (skor) untuk usahatani padi ke $\mathrm{i}$

$\mathrm{D}_{1}=\operatorname{musim}$ tanam $($ dummy $) ; \mathrm{D}=1$ musim hujan, $\mathrm{D}=0$ musim kemarau

$\mathrm{v}_{\mathrm{it}}=\mathrm{V}_{\mathrm{i}}$ adalah variabel random yang diasumsikan iid (identicallyindependenly distributed)

$\mathrm{u}_{\mathrm{it}}=\quad \mathrm{u}_{\mathrm{i}}$ yang merupakan variabel random non-negatif random yangdiasumsikan disebabkan oleh inefisiensi teknis dalam produksi danjuga sering diasumsikan sebagai iid

$\hat{\mathrm{a}}_{1}, \ldots . \hat{\mathrm{a}}_{10}=$ parameter fungsi yang diduga

Langkah selanjutnya adalah menghitung efisiensi teknik (TE) yang diukur dengan:

$$
T E=\frac{y_{i}}{\exp \left(x_{i} \beta\right)}=\frac{\exp \left(x_{i} \beta-u_{i}\right)}{\exp \left(x_{i} \beta\right)}=\exp \left(-u_{i}\right)
$$

Untuk melihat pengaruh karakteristik struktural dan manajerial terhadap efisiensi teknis, ke dalam model ditambahkan variabel karakteristik struktural dan manajerial, sehingga persamaan yang dimasukkan ke dalam fungsi produksi dan efek inefisiensi menjadi:
$\operatorname{Ln} Y_{i}=\hat{a} o+\hat{a}_{1} \ln X_{1}+\hat{a}_{2} \ln X_{2}+\hat{a}_{3} \ln X_{3}+\hat{a}_{4} \ln X_{4}+\hat{a}_{5} \ln$ $X_{5}+\hat{a}_{6} \ln X_{6}+\hat{a}_{7} \ln X_{7}+\hat{a}_{8} \ln X_{8}+d_{1} D_{1}+\ddot{a}_{0}+\ddot{a}_{1} Z_{1}+\ddot{a}_{2} Z_{2}+$ $\ddot{a}_{3} Z_{3}+\ddot{a}_{4} Z_{4}+\ddot{a}_{5} Z_{5}+\ddot{a}_{6} Z_{6}+\ddot{a}_{2} D_{2}+\ddot{a}_{3} D_{3}+\ddot{a}_{4} D_{4}+\ddot{a}_{5} D_{5}+v_{i}-$ $u_{i} \ldots \ldots . . . . .(3)$

Dengan :

$Z_{1}=$ umur petani (tahun)

$Z_{2}=$ pendidikan petani (tahun)

$\mathrm{Z}_{3}=$ pengalaman berusahatani (tahun)

$\mathrm{Z}_{4}=$ Jumlah anggota keluarga

$Z_{5}=$ jarak sumber irigasi

$\mathrm{Z}_{6}=$ pendapatan luar usahatani

$\mathrm{D}_{2}=$ dummy akses terhadap kredit $(\mathrm{D}=1$; petani mempunyai akses, $\mathrm{D}=0$ bila tidak)

$\mathrm{D}_{3}=$ dummy status kepemilikan lahan $(\mathrm{D}=1$ bila lahan milik; D = Olainnya (sewa, garap))

$\mathrm{D}_{4}=$ dummy partisipasi dalam kelompok $(\mathrm{D}=1$ bila aktif; $\mathrm{D}=0$ bila tidak)

$\mathrm{D}_{5}=$ dummy lokasi kawasan $(\mathrm{D}=1$ bila pedesaan, $\mathrm{D}=0$ bila peri urban)

Pendugaan parameter fungsi produksi dan fungsi inefisiensi teknis untuk padi pada persamaaan di atas dilakukan secara simultan menggunakan program Frontier 4.1. (Coelli, 1996). Pengujian parameter stochastic frontier dan efek inefisiensi dilakukan dalam dua tahap. Tahap pertama merupakan pendugaan parameter $\ddot{a}_{i}$ dengan menggunakan metode OLS, sedangkan tahap dua dilakukan pengujian menggunakan Maximum Likelihood Estimator (MLE) untuk mengestimasi pendugaan seluruh parameter $\ddot{a}_{i}$ (kecuali $\ddot{a}_{0}$ ) dan ó serta varians $\grave{i}_{i}$ dan $v_{i}$. Parameter dari nilai varians dapat mengestimasi nilai ã sehingga nilai Od" ã d" 1 . Nilai ã merupakan kontribusi efisiensi teknis di dalam efek residual total.

\section{HASIL DAN PEMBAHASAN FUNGSI PRODUKSI DAN EFISIENSI TEKNIS USAHATANI PADI}

Berdasarkan analisis fungsi produksi model stochastic frontier dengan maksimum likelihood dapat diestimasi faktorfaktor yang mempengaruhi produksi serta efek inefisiensi serta besarnya efisiensi teknis pada usahatani padi di Kabupaten Sleman. Variabel bebas yang diduga berpengaruh terhadap produksi usahatani padi adalah luas lahan, penggunaan benih, pestisida, pupuk nitrogen, phosphor dan organik, serta penggunaan penggunaan 
tenaga kerja. Faktor lingkungan yang diduga berpengaruh adalah besarnya pencemaran irigasi, musim tanam dan lokasi usahatani padi.

Hasil analisis diperoleh nilai likelihood ratio (LR) sebesar 40,92 lebih besar dari nilai chi-square

( $\chi^{2}$ - tabel á $1 \%$ ) sebesar 21,666 sehingga variabel independen secara bersama-sama berpengaruh nyata terhadap variabel dependen. Dengan demikian luas lahan, jumlah benih, jumlah pestisida, jumlah $\mathrm{N}$, jumlah $\mathrm{P}$, jumlah pupuk $\mathrm{O}$, jumlah tenaga kerja luar keluarga, polusi irigasi serta dummy musim tanam secara bersamasama berpengaruh secara signifikan terhadap produksi usahatani padi. Secara rinci hasil estimasi fungsi produksi stochastic frontier usahatani padi disajikan pada Tabel 1.

Tabel 1. Estimasi Fungsi Produksi Stochastic Frontier Usahatani Padi di Kabupaten Sleman Tahun 2013/2014

\begin{tabular}{llll}
\hline Variabel & Parameter & Koefisien & T-Ratio \\
\hline Fungsi Produksi & & & \\
Intersep & $\beta_{0}$ & $-0,062^{\text {ns }}$ & $-0,040$ \\
Luas Lahan & $\beta_{1}$ & $0,913^{* * *}$ & 10,471 \\
Benih & $\beta_{2}$ & $0,307^{\text {ns }}$ & 0,340 \\
Pestisida & $\beta_{3}$ & $-0,611^{\text {ns }}$ & $-0,881$ \\
Pupuk N & $\beta_{4}$ & $0,001^{\text {ns }}$ & 0,060 \\
Pupuk P & $\beta_{5}$ & $-0,007^{\text {ns }}$ & $-0,740$ \\
Pupuk 0 & $\beta_{6}$ & $0,009^{*}$ & 1,711 \\
TK Luar Keluarga & $\beta_{7}$ & $-0,016^{\text {ns }}$ & $-1,421$ \\
Polusi irigasi & $\beta_{8}$ & $0,065^{\text {ns }}$ & 0,192 \\
Dmusim & $\mathrm{B}_{9}$ & $-0,083^{* *}$ & $-2,000$ \\
sigma-squared & $\sigma^{2}$ & 0,066 & 3,017 \\
Gamma & $\gamma$ & 0,817 & 3,679 \\
Log likelihood function & LLF & 19,111 & \\
LR Test of the one-side eror & & 40,922 & \\
\hline
\end{tabular}

Keterangan:

$* * *=$ Signifikan pada tingkat kesalahan (á) $1 \%$

** $=$ Signifikan pada tingkat kesalahan (á) 5\%

* $\quad$ Signifikan pada tingkat kesalahan (á) $10 \%$

ns $=$ tidak signifikan

Berdasarkan gambaran hasil terhadap variabel independen yang digunakan dalam model fungsi produksi, variabel yang berpengaruh positif dan signifikan yaitu luas lahan dan penggunaan pupuk organik. Koefisien luas lahan memiliki nilai paling besar dibanding koefisien variabel lainnya. Hasil analisis tersebut juga menunjukkan adanya perbedaan produksi padi secara signifikan antara musim hujan dengan musim kemarau.

Berdasarkan hasil estimasi fungsi produksi stochastic frontier diperoleh hasil yang menunjukkan bahwa variabel luas lahan berpengaruh positif dan signifikan pada taraf kepercayaan 99 persen terhadap produksi pada usahatani padi. Hal ini menunjukkan bahwa tingkat produksi berbanding lurus dengan luas lahan. Nilai koefisien variabel lahan pada model menunjukkan elastisitas variabel lahan terhadap produksi padi sebesar 0,913. Hal ini berarti peningkatan luas lahan sebesar satu persen akan mengkibatkan peningkatan produksi padi sebesar 0,913 persen, cateris paribus. Kondisi ini menjelaskan bahwa luas lahan usahatani padi berkorelasi positif terhadap luas panen tanaman padi sehingga berpengaruh terhadap peningkatan produksi padi.

Variabel pupuk $\mathrm{O}$ (organik) berpengaruh berpengaruh positif signifikan pada taraf kepercayaan 90 persen terhadap produksi pada usahatani padi. Hal ini menunjukkan bahwa tingkat produksi berbanding lurus dengan penggunaan pupuk organik. Nilai koefisien variabel pupuk organik pada model menunjukkan elastisitas variabel lahan terhadap produksi padi sebesar 0,009 . Hal ini berarti peningkatan pupuk organik sebesar satu persen akan mengkibatkan peningkatan produksi padi sebesar 0,009 persen, cateris paribus. Pupuk organik yang diberikan pada lahan akan memperbaiki kualitas tanah dengan penambahan bahan organik yang berkontribusi pada berkembangnya mikroorganisme lokal yang membantu proses penyerapan unsur hara oleh tanaman.

Variabel dummy musim tanam menunjukkan adanya perbedaan produksi antara musim hujan dengan musim kemarau secara signifikan pada taraf kepercayaan 95 persen. Nilai koefisien variabel dummy musim tanam pada model, produksi padi pada musim hujan lebih rendah (0,083\%) dibandingkan produksi pada musim kemarau. Perbedaan ini terjadi karena pada musim hujan sering terjadi ledakan hama yang dapat menyerang tanaman padi dan berdampak pada penurunan produksi padi.

Variabel polusi irigasi tidak berpengaruh secara signifikan pada taraf kepercayaan 90 persen terhadap produksi pada usahatani padi. Hal ini menunjukkan 
TABEL 2. SEBARAN EFIIIENSI TEKNIS USAHATANI PADI DI D.I. YOGYAKARTA TAHUN 2013/2014

\begin{tabular}{lllll}
\hline \multirow{2}{*}{$\begin{array}{l}\text { Kelompok Efisiensi } \\
\text { Teknis }\end{array}$} & \multicolumn{2}{c}{ MUSIM HUJAN } & \multicolumn{2}{c}{ MUSIM KEMARAU } \\
\cline { 2 - 5 } & Jumlah Petani & Persentase (\%) & Jumlah Petani & Persentase (\%) \\
\hline 0,40 & 3 & 6,0 & 3 & 6,0 \\
0,50 & 2 & 4,0 & 7 & 14,0 \\
0,60 & 11 & 22,0 & 10 & 20,0 \\
0,70 & 9 & 18,0 & 6 & 12,0 \\
0,80 & 20 & 40,0 & 13 & 26,0 \\
0,90 & 5 & 10,0 & 11 & 22,0 \\
Jumlah & 50 & 100,0 & 50 & 100,0 \\
Rata-rata TE & 0,768 & & 0,749 & \\
Minimum TE & 0,411 & & 0.403 & \\
Maksimum TE & 0,955 & & 0,951 & \\
\hline
\end{tabular}

bahwa kualitas irigasi di Kabupaten Sleman masih baik bagi usahatani padi. Tingkat pencemaran air irigasi masih belum berdampak terhadap penurunan produksi padi. Secara geografis lahan sawah di Kabuaten Sleman berada di bagian atas sebelah utara kota Yogyakarta serta dekat dengan sumber air irigasi sehingga tingkat pencemaran masih tergolong rendah, sehingga tidak memiliki dampak negatif bagi produksi padi.

Berdasarkan hasil analisis efisiensi teknis, data sebaran efisiensi teknis usahatani padi menunjukkan bahwa mayoritas nilai efisiensi pada kisaran 0,80 hingga 0,89 . Usahatani yang efisiensi teknisnya kurang dari 0,70 dikelola 16 orang petani $(32,0 \%)$ pada musim hujan, dan 20 orang petani $(40,0 \%)$ pada musim kemarau. Secara umum rata-rata efisiensi teknis usahatani padi sebesar 0,758 . Hal ini menunjukkan bahwa secara umum masih ada peluang peningkatan produksi padi sebesar 24,2 persen untuk mencapai produksi maksimum. Terjadi perbedaan efisiensi usahatani padi antara musim hujan dengan musim kemarau. Efisiensi teknis usahatani padi pada musim hujan lebih tinggi daripada musim kemarau. Hal ini menunjukkan bahwa produksi potensial pada musim kemarau lebih tinggi daripada produksi potensial pada musim hujan.

\section{PENGARUH KARAKTERISTIK STRUKTURAL PETANI TERHADAP EFISIENSI USAHATANI PADI}

Faktor-faktor yang mempengaruhi tingkat efisiensi teknis petani responden dianalisis dengan menggunakan model efek inefisiensi teknis dari fungsi produksi stochastic frontier. Tabel 3 menyajikan hasil analsis faktor-faktor yang mempengarui tingkat efisiensi teknis usahatani padi di Kabupaten Sleman.

Berdasarkan hasil pendugaan model efek inefisiensi teknis, diketahui bahwa faktor struktural jarak sumber irigasi dan lokasi usahatani berpengaruh positif secara signifikan terhadap inefisiensi usahatani padi. Kondisi irigasi berpengaruh terhadap efisiensi usahatani padi, yakni makin jauh jarak sumber irigasi terhadap lahan usahatani padi maka usahatani padi makin tidak efisien. Hal ini menunjukkan bahwa pengelolaan irigasi masih belum sepenuhnya memenuhi kebutuhan irigasi usahatai padi. Lahan yang jauh dari sumber irigasi tidak mendapat jatah irigasi yang sesuai kebutuhan, sehingga produksi padi tidak bisa maksimal.

TABEL 3. ESTIMASI FUNGSI PRODUKSI STOCHASTIC FRONTIER MODEL INEFISIENSI USAHATANI PADI DENGAN METODE MLE

\begin{tabular}{lccc}
\hline Variabel & Parameter & Koefisien & T-Ratio \\
\hline Model Inefisiensi & & & \\
Intersep & $\delta_{0}$ & $-0,496^{\text {ns }}$ & $-0,791$ \\
Umur & $\delta_{1}$ & $0,011^{*}$ & 1,565 \\
Pendidikan & $\delta_{2}$ & $-0,004^{\text {ns }}$ & $-0,289$ \\
Pengalaman & $\delta_{3}$ & $-0,007^{*}$ & $-1,573$ \\
Jml anggota keluarga & $\delta_{4}$ & $0,001^{\text {ns }}$ & 0,007 \\
Jarak sumber irigasi & $\delta_{5}$ & $0,059^{*}$ & 1,758 \\
Pendapatan luar UT & $\delta_{6}$ & $0,001^{*}$ & 1,861 \\
Dummy akses kredit & $\delta_{7}$ & $-0,212^{*}$ & $-1,665$ \\
Dummy status lahan garapan & $\delta_{8}$ & $0,089^{\text {ns }}$ & 0,699 \\
Dummy partisipasi kelompok & $\delta_{9}$ & $0,001^{\text {ns }}$ & 0,004 \\
Dummy lokasi desa & $\delta_{10}$ & $0,364^{* *}$ & 2,066 \\
\hline
\end{tabular}

Keterangan :

** = Signifikan pada tingkat kesalahan(á) 5\%

* $\quad$ Signifikan pada tingkat kesalahan(á) 10\%

$\mathrm{N}_{s}=$ tidak signifikan

Koefisien variabel dummy lokasi desa bernilai positif yang menunjukkan usahatani padi yang dijalankan di kawasan pedesaan lebih inefisien dibanding usahatani padi yang dijalankan kawasan peri urban. Hal ini menunjukkan bahwa tekanan terhadap sektor pertanian di kawasan peri urban 
mendorong petani menjalankan usahatani lebih serius, sehingga usahatani di kawasan peri urban lebih efisien secara teknis. Masyarakat yang bertahan dengan usaha bidang pertanian di kawasan peri urban akan berusaha mengelola sumberdaya yang dimiliki secara optimal agar memberikan sumbangan pendapatan yang layak bagi ekonomi rumah tangganya.

\section{PENGARUH KARAKTERISTIK MANAJERIAL PETANI TERHADAP EFISIENSI USAHATANI PADI}

Van Passel (2006) menyebutkan bahwa faktor karakteristik manajerial petani adalah faktor agen yang terdiri atas umur, pendidikan, pengalaman, trainingpenyuluhan, jender dan sebagainya. Hasil analisis model efek inefisiensi menunjukkan bahwa faktor karakteristik manajerial petani yang berpengaruh terhadap inefisiensi teknis adalah variabel umur dan pendapatan luar usahatani. Kedua variabel tersebut berkorelasi positif signifikan dengan inefisiensi teknis usahatani padi. Sementara itu, pengalaman petani dan dummy akses terhadap kredit berkorelasi negatif dan signifikan terhadap inefisiensi teknis usahatani padi.

Berdasarkan hasil analisis model efek inefisiensi di atas dapat dijelaskan bahwa semakin tinggi umur dan pendapatan luar usahatani petani, maka usahatani makin tidak efisien. Hal ini terjadi karena sebagian besar petani berusia lanjut, termasuk kategori tidak produktif lagi sehingga kemampuan mengelola usahatani sudah turun dan berdampak pada turunnya efisiensi teknis usahatani padi. Sementara itu bagi petani yang memiliki sumber pendapatan di luar usahatani, maka pendapatan luar usahatani yang makin tinggi akan menjadi prioritas kegiatan dibanding kegiatan usahatani. Dengan demikian kegiatan usahatani akan makin tidak efisien secara teknis.

Koefisien variabel pengalaman dan dummy akses terhadap kredit bernilai negatif menunjukkan bahwa semakin lama pengalaman yang dimiliki petani maka usahatani yang dijalankan akan makin efisien secara teknis. Pengalaman menjalankan usahatani akan memberikan pengetahuan dan keterampilan baik keterampilan teknis maupun manajerial yang dapat meningkatkan kemampuan menjalankan usahatani padi. Sementara itu petani yang memiliki akses terhadap kredit akan lebih efisien dibanding petani yang tidak memiliki akses terhadap kredit. Kewajiban terhadap pengembalian kredit mendorong petani untuk menjalankan usahatani padi lebih seirus agar dapat menunaikan kewajiban terhadap pengembalian pinjaman kredit yang diambil. Hal ini akan berdampak pada perbaikan tingkat efisiensi teknis usahatani padi.

\section{KESIMPULAN}

Faktor-faktor yang mempengaruhi produksi padi adalah luas lahan, penggunaan pupuk organik dan musim tanam. Luas lahan dan penggunaan pupuk organik berpengaruh positif terhadap produksi padi. Sementara itu, produksi padi musim hujan lebih rendah dibanding musim kemarau.

Berdasarkan hasil pendugaan model efek inefisiensi teknis, diketahui bahwa faktor struktural, jarak sumber irigasi dan lokasi usahatani, berpengaruh positif secara signifikan terhadap inefisiensi usahatani padi. Faktor karakteristik manajerial petani, variabel umur dan pendapatan luar usahatani, berkorelasi positif signifikan dengan inefisiensi teknis usahatani padi. Sementara pengalaman petani dan dummy akses terhadap kredit berkorelasi negatif dan signifikan terhadap inefisiensi teknis usahatani padi.

Dalam upaya peningkatan produktivitas dan efisiensi usahatani padi, maka perlu diperhatikan faktor struktural dan manjerial petani dengan peningkatan keterampilan dan kapasitas manajemen petani melalui pelatihan dan penguatan modal usahatani yang memadai. Selain itu, perlu upaya peningkatan luas tanam serta perbaikan pengelolaan layanan air irigasi yang mampu menjangkau dan memenuhi kebutuhan air irigasi secara kontinyu.

\section{DAFTAR PUSTAKA}

Abedullah, B. Khuda and A. Bashir. 2006. Technical efficiency and its determinants in potato production, evidence from Punjab, Pakistan. The Lahore Journal of Economics 11(2): 1-22.

Ahmad, M., M.C. Ghulam, and I. Mohammad. 2002. Wheat productivity, efficiency, and sustainability: a stocastic production frontier analysis. The Pakistan Development Review 41(4): 643-663.

Anonim. 2009. Jumlah Bendung Irigasi Kabupaten Bantul. Dinas PU dan ESDM Kabupaten Bantul.

Bakhsh, K., and H. Sarfraz. 2008. Relationship between technical efficiency and managerial ability evidence from Punjab, Pakistan. http://www.wbiconpro.com/ Management/411-Bakhsh,L \%20\&\%20 Hassan,S.pdf. 
Basnayake, B. M. J. K. and LHP Gunaratne. 2002. 'Estimation of technical efficiency and it's determinants in the tea small holding sector in the Mid Country Wet Zone of Sri Lanka. Sri Lanka Journal of Agricultural Economics 4: 137-150.

BLH. 2013. Kualitas Air Sungai di Daerah Istimewa Yogyakarta. Yogyakarta: Badan Lingkungan Hidup Provinsi D.I Yogyakarta.

Bozoglu, and V. Ceyhan. 2007. Measuring the technical efficiency and exploring the inefficiency determinant of vegetable farms in Samsung Province, Turkey. Agric. Syst. 94: 649-656.

BPS. 2013a. Bantul Dalam Angka. Bantul: BPS Kabupaten Bantul.

2013 ${ }^{\mathrm{b}}$. Sleman Dalam Angka. Sleman: BPS Kabupaten Sleman.

. 2013c. Statistik Indonesia. Jakarta: BPS Jakarta.

2013․ Yogyakarta Dalam Angka. Yogyakarta: BPS D.I. Yogyakarta.

Bravo-Ureta, B, E, Sol.s, D., V. Moreira, J. Maripani, A. Thiam, and T. Rivas. 2007. Technical efficiency in farming: a meta-regression analysis. Journal of Productivity Analysis 27: 57-72.

Coelli, T., 1996. Frontier Version 4.1: A Computer Program for Stochastic Frontier Production and Cost Function Estimation. Working Paper 96/7, CEPA, Departemen of Econometrics University of New England, Armidale, Australia.

Hasan, M. K., and S. M. F. Islam. 2010. Technical ineficiency of wheat production in some selected areas of Bangladesh. Bangladesh Journal Agril. Res. 35(1): 101112.

Meuya, EE. Hisano, S and Nariu, T. 2008. Explaining productivity variation among smallholder maize farmers in Tanzania. MPRA Paper No. 14626, posted 17. April 2009 / 15:03. Online at http:// mpra.ub.unimuenchen.de/14626/

Obare, G.A., D.O.Nyagaka, W. Nguyo, and S.M. Mwakubo. (2010). Are Kenyan smallholders allocatively efficient? evidence from irish potato producers in Nyandarua North District. Journal of Development and Agricultural Economics 2(3): 78 - 85. Ogundari, K. and S.O. Ojo. 2006. An examination of technical, economic and allocative efficiency of small farm: the case study of cassava farmers in Osun State of Nigeria. Journal Central European Agriculture 7(3): 423-432.

Okike, I., M.A. Jabbar., V.M. Manyong, J.W. Smith, and S.K. Ehui. 2004. Factors affecting farm-specific production efficiency in savanna zones of West Africa. Journal of African Economics 13(1): 134-165.

Sauer, J. and J.M. Abdallah. 2007. Forest diversity, tobacco production and resource management in Tanzania. Forest Policy and Economics 9:421-439. Doi:10.1016/ j.forpol.2005.10.1007

Sharma, K.R., N.C. Pradhan, and P.S. Leung. 2000. Stochastic frontier approach to measuring irrigation performance: an application to rice production under the two systems in the Tarai of Nepal. Water Resources Research 37(7). doi:10.1029/2000WR900407

Sherlund, M. S., C. B.Barret \& A.A. Adesina. 2002. Smallholder technical efficiency controlling for environtment production condition. Journal of Development Economics 69 (2002): 85 - 101.

Tchale, H. and J.Sauer. 2007. The efficiency of maize farming in Malawi. A bootstrapped translog frontier Cahiers d'Economie et Sociologie Rurales, vol. 82-83: 33-56.

Tchale, H. and J. Sauer. 2009. The efficiency of smallholder agriculture in Malawi. AFJARE 3(2).

Van Passel, S., L.Lauwers, \& G. Van Huylenbroeck. 2006. Factors of farm performance: an empirical analysis of structural and managerial characteristics, in: causes and impact of agricultural structure. http:// www.gapem.org/Text/VanPassel_etalFactorsFarmPerformance-Ch.pdf 